This is a self-archived version of an original article. This version may differ from the original in pagination and typographic details.

Author(s): Romashko, Tatiana

Title: Biopolitics and Hegemony in Contemporary Russian Cultural Policy

Year: 2018

Version: Accepted version (Final draft)

Copyright: @ 2018 Koninklijke Brill NV

Rights: In Copyright

Rights url: http://rightsstatements.org/page//nC/1.0/?language=en

Please cite the original version:

Romashko, T. (2018). Biopolitics and Hegemony in Contemporary Russian Cultural Policy.

Russian Politics, 3(1), 88-113. https://doi.org/10.1163/2451-8921-00301005 


\title{
Biopolitics and Hegemony in Contemporary Russian Cultural Policy
}

Tatiana Romashko

University of Jyvaskyla, Finland; Herzen University, Russia

tatiana.t.romashko@jyu.fi

\begin{abstract}
Since 2011, Russian 'licensing civil society' ${ }^{1}$ has predominated through censorship and the restrictive regulation of arts and cultural societies. The current conservative project has turned artistic space into public space, indicating moral abuse and a threat to the spiritual health of the Russian nation. Consequently, the symbolic borders of human creativity and individual freedom in arts and cultural societies have been reduced to patriotism, nationalism and moral deductive functions of the state-approved program. This paper will explore Russian state cultural policy and argue that biopolitics is its mainstream strategy. It examines how the ensemble of sovereign and disciplinary power defines and instrumentalizes the concept of culture while also producing lines of inclusion and exclusion within the conservative political project. The major emphasis is placed on the question of political control over the body, spirit and national identity.
\end{abstract}

\section{Keywords}

Russian biopolitics - cultural policy discourses - censorship of the arts - hegemony

${ }^{1}$ Graeme Robertson, "Managing Society: Protest, Civil Society, and Regime in Putin's Russia", Slavic Review 68, no. 3 (2009): 528-547. 
During the autumn of 2016 (September and October), a cultural event was discussed extensively in the Russian media and social networks. These discussions stemmed from a photo exhibition titled Without Embarrassment by the American photographer Jock Sturges at the Brothers Lumiere Center in Moscow, where images of nudist families were displayed. A senior citizen reported the exhibition to the local prosecutor's office on the grounds that the exhibition threatened Russian moral norms. According to a news report, even though the local prosecutor did not find that any law had been violated and rejected the allegation, patriotic representatives of the Moscow authorities denounced the exhibition as abusive to minors inasmuch as the pictures showed naked young girls. 'This is propaganda of paedophilia in the most accurate sense of the word', Senator Elena Mizulina commented on state television. ${ }^{2}$ Finally, the exhibition was blocked by activists of 'Officers of Russia' and the 'Center for Prevention of Offenses' (http://oficery.ru/), a non-governmental organization with tight connections to the Kremlin ${ }^{3}$ (translated by the author from Russian). Hence the exhibition was stopped by a public organization 'from below' without direct political authorization. $^{4}$

2 "Russian NGO blocks entrance to Jock Sturges exhibition in Moscow", Rossiskaya Gazeta, 25 September 2016, https://www.rbth.com/news/2016/09/25/russian-ngo-blocks-entrance-to-jocksturges-exhibition-in-moscow_633043 (accessed 10 October 2017).

${ }^{3}$ Eugene Berg, “Ofitsery Rossii: kto oni takie?" [“Officers of Russia: Who are they?”], Meduza, 27 September 2016, https://meduza.io/feature/2016/09/27/ofitsery-rossii-kto-oni-takie (accessed 10 February 2017).

4 "Officers of Russia deny concluding contract with Russian Railways to patrol trains for 118 million roubles", Crime Russia, 13 September 2017, https://en.crimerussia.com/gromkie-dela/officersofrussia-deny-concluding-contract-with-russian-railways-to-patrol-trains-for-118-million-r/ (accessed 20 September 2017). 
A group of Russian researchers ${ }^{5}$ have investigated how hostile the opposition to the exhibition was. The pro-censorship discourse described the 'naked human body', which was displayed in a public space, as a threat to Russian traditional norms and Russian Orthodox morality. In general, these negative responses were presented on Russian television in positive terms. In addition to the aggressive Kremlin rhetoric and the accusation of the demoralization of the national culture made by representatives of nationalistic circles and the Russian Orthodox Church, several television channels reported an incident when a man poured urine out of a plastic bottle onto some of the photographs and shouted: 'This should be the position of every Russian. Our culture should be Russian. We don't need European culture here ${ }^{9}$ (emphasis added). Further, the socially constructed 'taboo' on naked bodies extended to social networks: "supporters of the taboo, which formed the first "discursive community", mostly used offensive names originating from the discourse of power, such as "paedophile" exhibition ${ }^{7}$ (translated by the author from Russian).

These antagonistic examples are not the spontaneous responses of Russian citizens but the effects of contemporary Russian cultural policy. The cultural policy of the Russian state has become a tool of marginalization and sociocultural separation. The strategy of

\footnotetext{
${ }^{5}$ Alexandra Arkhipova, Maria Volkova, Leta Yugay and Anna Kiresiuk, "Pochemu Mizulina - eto seksi, a nagota - eto strashno?" ["Why Mizulina is sexy but nude - is it scary?"], Colta, 14 October 2016, http://www.colta.ru/articles/society/12745 (accessed 20 October 2016).

6 Will Stewart, "US photographer is accused of creating child pornography as pro-Kremlin demonstrator throws urine at images of naked children during exhibition in Moscow”, Daily Mail, 26 September 2016, http://www.dailymail.co.uk/news/article-3807438/US-photographer-accusedcreating-childpornography-pro-Kremlin-demonstrator-throws-urine-images-naked-childrenexhibitionMoscow.html (accessed 26 September 2016).
}

${ }^{7}$ Arkhipova, "Pochemu Mizulina - eto seksi, a nagota - eto strashno?" 
establishing cultural borders between Russia and the EU countries, on the one hand, and reducing Russian society to a single national identity, on the other, creates a 'common sense' which subordinates cultural policy to the internal and external requirements of the Russian state's hegemonic project. In the past five years, the culture and art sphere in Russia has been provided, monitored, restricted and censored by the conservative regime of the 'one-party government ${ }^{9}$. Since the Pussy Riot punk performance in the Cathedral of Christ the Savior in Moscow and the reinforcement of security legislation after the wave of civic protests that erupted before and after the 2012 presidential elections, this process has accelerated and intensified ${ }^{9}$. The art sphere has lost its relative autonomy and many public spaces have been appropriated by the state. There are two main aspects of this process through which popular consent has been produced.

Firstly, the reinforcement of administrative legislation ${ }^{10}$ has provided a basis for the criminalization of heterogeneity, ambiguity and dissidence, no matter where it occurs, e.g. online or outdoors, in a Russian Orthodox church or a private theatre. Recently banned theatre performances (e.g. the rock opera Jesus Christ Superstar at the Omsk State Music

8 Vladimir Gel'man, Authoritarian Russia: Analyzing Post-Soviet Regime Changes (Pitsburg: University of Pitsburg, 2015): 90.

${ }^{9}$ Andrey Makarychev and Sergei Medvedev, "Biopolitics and Power in Putin's Russia", Problems of Post-Communism 62, no. 1 (2015): 45-54.

10 See "Amendments to the Code of Administrative Offences and the Law on Rallies" (http://en.kremlin.ru/acts/news/15608/print) No. 65-FZ of 8 July 2012; "On Rallies, Meetings, Demonstrations, Marches and Picketing" (http://www.consultant.ru/document/cons_doc_LAW_130936/); "Law on Informational Security", 2013, etc. 
Theatre $^{11}$, the Nureyev ballet at the Bolshoi Theatre in Moscow ${ }^{12}$, etc.) and heated debates around 'unwanted' films (e.g. the documentary Under the Sun by Vitaly Mansky, the movies Leviathan by Andrey Zvyagintsev and Matilda by Alexei Uchitel ${ }^{13}$ ) are some of the most widely reported examples of conservative opposition to contemporary culture in Russia. In many cases, state opposition, even to culture that it has funded, is stimulated by highly visible conservative and traditionalist critics and the various organizations that support them. In the official discourse, the idea of 'true culture' is often ideologically grounded in traditionalism, nationalism and Orthodox conservatism ${ }^{14}$, which are associated with the sovereignty of the Russian state and its 'responsibility to protect." 15 These examples illustrate that the

11 "Russia: Jesus Christ Superstar cancellation highlights growing nationalist threat to freedom of $\begin{array}{lllll}\text { expression", } & \text { Amnesty } & \text { International, } & 18 & \text { October }\end{array}$ https://www.amnesty.org/en/latest/news/2016/10/russia-jesus-christ-superstar-cancellation-highlights growing-nationalist-threat-to-freedom-of-expression/ (accessed 10 April 2017).

${ }^{12}$ Shaun Walker, "Shock as Bolshoi cancels world premiere of Nureyev ballet", The Guardian, 9 July 2017, https://www.theguardian.com/stage/2017/jul/09/shock-as-bolshoi-cancels-world-premiere-ofnureyev-ballet (accessed 10 July 2017).

13 Juri Rescheto, "Russia threatens to forbid 'Matilda,' a film about Tsar Nikolai II's love life", Deutsche Welle, 8 February 2017, http://www.dw.com/en/russia-threatens-to-forbid-matilda-a-filmabout-tsarnikolai-iis-love-life/a-37459910 (accessed 10 February 2017).

${ }^{14}$ Igor Torbakov, "Defining the 'True' Nationalism: Russian Ethnic Nationalists versus Eurasianists", in Mark Bassin and Gonzalo Pozo eds., The Politics of Eurosianism: Identity, Popular Culture and Russia's Foreign Policy. (London: Rowman and Littlefield International, 2017): 19-38; Maria Shteynman, "Political Myth and Political Glory: Shaping Media Reality", Russian Sociological Review 15, no. 4 (2016): 96-112.

${ }^{15}$ Charles E. Ziegler, "Russia on the rebound: using and misusing the Responsibility to Protect", International Relations 30, no. 3 (2016): 346-361. 
reinforcement of security policy and 'national defence' takes place not only at the territorial or physical borders of the country but also in the spiritual, moral and cultural dimensions of the collective body of individuals. They demonstrate that Russian cultural policy is formed as an intervention in the ordinary and everyday culture, which, as Gramsci and subsequently Hall have argued, is the terrain on which hegemony is established.

Secondly, the Russian state does not act on culture simply through cultural means, but also through law and regulation. Russian cultural policy is implemented through law. The introduction of restrictive laws and amendments ${ }^{16}$ creates the conditions for the political and economic dependence of the arts and cultural sphere ${ }^{17}$ on the state, and at the same time confines cultural production to the regulated national sphere. These legal actions reverse and erase previous developments at the level of the state which had recognized a 'cosmopolitan' idea of culture as well as its market-centric economic dimension. According to the Federal Law on Foreign Agents (2012), non-governmental and non-profit organizations, as well as religious and civic communities, are not permitted to receive funding from abroad. Taking into account the poor economic conditions inside the country, national legislation has put the third sector along with private citizens into a position of complete dependence on the state bureaucratic apparatus, thus constraining the autonomy of civil society. Recent research on the subject ${ }^{18}$ points out that Russian NGOs tend to develop strategies of adaptation to the new

${ }^{16}$ Examples of federal laws of the Russian Federation: "Foreign Agent Law", 2013; "Principles of State Cultural Policy", 2014, etc.

${ }^{17}$ Maria Lipman, “At the Turning Point to Repression”, Russian Politics \& Law 54, no. 4 (2016): 341-350.

${ }^{18}$ Andrey Semenov and Vsevolod Bederson, "Organizatsionnye reaktsii rossiyskikh NKO na zakonodatel'nye izmeneniya 2012 g." [“Organizational Reactions of Russian NGOs to 2012 
order of power relations rather than display community cohesion and campaign against restrictive legislation that violates the rights ${ }^{19}$ of freedom of speech, cultural autonomy and creative work. It is on that basis that the state has enforced a more prescriptive position in relation to 'true Russian culture', in many ways responding to demands from conservative and traditional, including religious Orthodox, individuals and organizations.

The Russian state has not imposed the conservative cultural environment. It has acted on it to regulate and direct it. In that respect, the hegemonic project is supported by biopolitical techniques of governing. There is significant data that reveals how the contemporary Russian regime garners mass support. According to polls conducted by both the state-affiliated VZIOM ${ }^{20}$ Institute and the relatively autonomous Levada Center, ${ }^{21}$ the majority (86\%) of Russians agree with the current conservative policy. The purpose of this

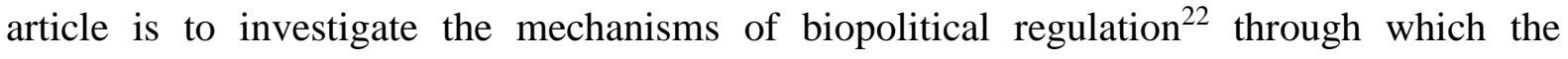
conservative cultural policy is normalized and naturalized and becomes hegemonic. The main

legislative Changes"], Ekonomicheskaya sotsiologiya [Journal of Economic Sociology] 18, no. 2 (2017): 11-40.

${ }^{19}$ Which were given by the first federal law on culture, 1992.

20 "Reiting Putina - na novoi rekordnoi vysote" ["Putin's rating is at a new record altitude"], Vserossiiskij Centr Izucheniya Obshchestvennogo Mneniya (VZIOM), Press-vypusk 2958, 22 October 2015, https://wciom.ru/index.php?id=236\&uid=115438 (accessed 10 December 2016).

21 "Noyabr'skie reitingi odobreniya i doveriya" ["The November approval ratings and trust"], Levada Center, 23 November 2016, http://www.levada.ru/2016/11/23/noyabrskie-reitingi-odobreniyaidoveriya-4/ (accessed 10 December 2016).

${ }^{22}$ Michel Foucault, Graham Burchell and Arnold Davidson, The Birth of Biopolitics. Lectures at the Collège de France, 1978-1979 (Hampshire: Palgrave Macmillan, 2008). 
question is how hegemonic functions maintain the stability of a particular 'regime of truth'23 and what governmental techniques are involved in this. For that reason, the paper focuses on the evidence of legal and administrative intervention in order to show that through them hegemonic chains of equivalence are established in which 'social antagonism and the division of the social are pushed to the margins of the society ${ }^{24}$ in order to create a social center around a 'unitary subject'. ${ }^{25}$ To put it more simply, the main attention of the paper is paid to the question of how the normative discourses of Russian state cultural policy attempt to reshape the affective identifications of citizens around a set of coherent symbols of the conservative project, therefore totalizing the 'subject' within them.

This paper starts with a discursive analysis of recent official documents on culture and its regulation in order to disclose the ideological framework of Russian state cultural policy. I specifically discuss some attempts of the conservative project to rearticulate the concepts of culture and to justify the rejection of Western culture. I then go on to show how they support the current Russian state's hegemonic project. Before doing so, I will lay out the main methodological framework of the study.

\section{Hegemony, Biopolitics and Russian Cultural Policy}

This paper aims to supplement a hegemonic approach to the analysis of political regimes which, following Gramsci, Hall, and Laclau and Mouffe, emphasizes the basis of political leadership in consent, with the idea of biopolitics developed by Foucault, which draws

\footnotetext{
${ }^{23}$ Michel Foucault, "The political function of the intellectual”, Radical Philosophy 17, no. 13 (1977):
} $126-133$.

${ }^{24}$ David Howarth, Ernesto Laclau: Post-Marxism, Populism and Critique (Oxford: Routledge, 2015): 11.

${ }^{25}$ Stuart Hall, "Gramsci and Us”, in Martin James ed., Antonio Gramsci (Glasgow: Routledge, 2002): 27-238 
attention to a modern form of rule or 'governmentality' through which power aims to control and regulate the conduct of the life of populations. One reason for choosing this approach is that the notion of hegemony tends to focus on the symbolic and cultural dimension of discourse but does not have much to say about the different ways through which political rule is implemented. Both the hegemonic and biopolitical approaches tend to assume modern Western liberal democratic capitalist regimes as a norm against which other regimes such as authoritarianism and populism are measured. However, it would not be straightforward to make these assumptions in the case of Russia, not least because of its history but also because the contemporary conservative and traditionalist 'common sense' is opposed to Western political and economic forms. Nevertheless, since the fall of the Soviet Union, Russia has at several points attempted to construct a political regime informed by Western political values, and at other points attempted to neutralize or exclude those values from political space. Therefore, despite the fact that Russia is formally democratic, and on some accounts even neoliberal, the concern of this paper is with the contemporary conjuncture in which conservative and traditional values are dominant. Thus, on that basis to refer to 'hegemony' and 'biopolitics' is not to distort the Russian case by introducing irrelevant concepts. Moreover, it would be hard to deny that the Soviet regime maintained power hegemonically and through the regulation of individual conduct.

Laclau and Mouffe claim that hegemony is the basis of social relations. By that, they mean that any social order has a political and, thereby, contingent and temporary nature which was forgotten and 'taken for granted"26. Furthermore, in order to stabilize social order, the contingency of society is always masked as a set of ideological worldviews, naturalized in

\footnotetext{
${ }^{26}$ Chantal Mouffe, “Artistic Activism and Agonistic Spaces”, Art and Research 1, no. 2 (2007): 2.
} 
sedimentary 'common sense' 27 and folklore, normalized in laws and routinized by political practices and mass media. However, sociocultural structures are never complete since they are not isolated from the "context of exteriority' ${ }^{28}$. That is to say, a hegemonic regime is never complete and self-contained as it relies on practices of exclusion from the social order, and consequently it must rely on political actions which show its contingent and non-natural character, and these actions are subject to contestation. Hegemony is an ongoing process of establishing political leadership, which is supported by economic, social and cultural forces and, at the same time, is always at risk of being contested, subverted and challenged by counter-hegemonic forces. As Glynos and Howarth explain, 'social actors (whether individual or collective) are always partially situated in a particular social context, in which their "decisions" involve the foreclosure of some political options. ${ }^{29}$ To put it differently, cultural and social structures should be thought of as hegemonic and counter-hegemonic institutional processes.

Laclau's analysis of the logic of populism is particularly relevant to the Russian case. Laclau $^{30}$ stresses that social antagonism is both an outcome and a hegemonic function of populist logic, which divides society into two camps of 'the people' and 'the non-people'. But because social relations are contingent, in the sense that they are not necessary or essential, 'the people' itself is constructed through a hegemonic process. Following Laclau, Howarth claims that 'the articulation of populist discourse involves the drawing of political

\footnotetext{
${ }^{27}$ Antonio Gramsci, Selections from the prison notebooks (London: Lawrence and Wishart, 1971).

${ }^{28}$ Ernesto Laclau and Chantal Mouffe, Hegemony and Socialist Strategy (London: Verso. 2001): xii.

${ }^{29}$ James Glynos and David Howarth, "Structure, Agency and Power in Political Analysis: Beyond Contextualised Self-Interpretations”, Political Studies Review 6, no. 2 (2008): 163.

${ }^{30}$ Howarth, Ernesto Laclau, 45.
} 
frontiers, which, if successful, puts "the people" against a defined enemy or adversary" 31 . Any unconventional position becomes marginalized. As a result, the adversarial or 'agonistic' ${ }^{32}$ perspective of political debates is dissolved. Any dispute is converted into antagonism, which rejects the 'pluralistic nature of the social world" ${ }^{33}$ and creates a terrain of exclusion. However, Laclau and Mouffe's approach has little to say about the kind of governmental mechanism that is used to establish and normalize this state of things as a routinized regime of truth. Instead, Laclau and Mouffe tend to conceive the political terrain in terms of an opposition between the institutions of parliamentary democracy and a people or demos which is unable to find its representation within the former, thus revealing the narrow and ruling class-based character of liberal democracy.

Foucault's notion of biopolitics can help to overcome this weakness in the theory of hegemony. In his late lectures titled 'The Birth of Biopolitics,', Foucault attempted 'to show how the coupling of a set of practices and a regime of truth form an apparatus (dispositif) of knowledge-power that effectively marks out in reality that which does not exist and legitimately submits it to the division between true and false ${ }^{34}$ (emphasis is original). Since that time, the biopolitical rationalization of individual and collective lives has been shown to be a complex of party-state policies (e.g. forms of interventions, procedures of control and strategies of discipline), which tend to provide social security and stability, and justice and

\footnotetext{
${ }^{31}$ Ibid., 13.

${ }^{32}$ Mouffe, Artistic Activism, 16.

${ }^{33}$ Ibid., 154.

${ }^{34}$ Michel Foucault, Graham Burchell and Arnold Davidson, The Birth of Biopolitics Lectures at the Collège de France, 1978-1979 (London: Palgrave Macmillan, 2008): 19.
} 
liberty $^{35}$. In this respect, the reinforcement of the conservative paternalistic and restrictive functions of Russian state cultural policy can be interpreted as an adjustment of the biopolitical regulation of national identity to the antagonistic geopolitical agenda. The justification of censorship and defensive priorities of the policy occurs through a deployment of general securitization and cultural hegemony. In fact, the newly constructed lines of inclusion and exclusion have marginalized a range of political activities on the cultural terrain and reduced the space for what Mouffe calls 'political agonism', the presence of free and diverse 'political options'. In order to secure hegemonic social closure, the official discourses of the 'power bloc' have a biopolitical effect on the life and conduct of the population as ideological and repressive state apparatuses have the authority to determine, produce and reproduce the strategies of discipline and punishment, which establish a specific dispositif of power relations in society.

In particular, it can be said that Russian biopolitics as a governmental technology produces ideologically 'recognized' ${ }^{36}$ membership in civil society, which is possible in the context of exercising cultural hegemony by the ruling class. Hastily adopted federal laws, unconditional presidential decrees and strategic documents of the ruling party and state have commissioned think tanks to generate a frame of requirements for citizens to follow in order to obtain the social acceptance of communal membership and to exercise 'the right to rights ${ }^{37}$. In this way, the official discourses of Russian state cultural policy can be considered

35 See for example Wendy Brown, Undoing the Demos Neoliberalism's Stealth Revolution (Cambridge: MIT Press, 2015).

${ }^{36}$ Louis Althusser, "Ideology and Ideological State Apparatuses", in Ben Brewster transl., Lenin and Philosophy and Other Essays (New York: Monthly Review Press, 1971): 185.

37 Judith Butler and Gayatri Chakravorty Spivak, Who Sings the Nation-State? Language, Politics, Belonging (London: Seagull Books, 2007): 65. 
a result of the biopolitical rhetoric of the "subaltern group' ${ }^{38}$, e.g. state-commissioned scientific or academic structures and government-affiliated NGOs, which reproduces the repetition of one-party state indoctrination. The argument of this paper is that there is some evidence to suggest that these discourses are constructed through chains of equivalence in which culture as an 'empty signifier' ${ }^{39}$ plays a double role. On the one hand, it supports a sense of a Russian civilizational identity based on essentialist notions of 'soul' and 'Russian spiritual bonds ${ }^{30}$. On the other hand, references to culture are aimed at creating antagonism towards inclusiveness, heterogeneity, contingency and diversity of a common culture ${ }^{41}$ insofar as these values are figured as non-Russian and pro-Western. However, the important point is that the symbolic dimension of discourse is grounded in the political transformation of the legal apparatus through which culture and the Russian unitary subject are regulated and governed.

\section{State Cultural Policy: Pre-2012 and Post-2012 Types of Design}

In order to stress the contingent and historical character of the conservative and traditional cultural hegemony in Russia, this section looks at the pre-2012 and post-2012 period of legislative activity on culture, respectively. An attempt is made to show how the conservative

${ }^{38}$ Gayatri Chakravorty Spivak, "Can the Subaltern Speak?" in C. Nelson and L. Grossberg eds., Marxism and Interpretation of Culture (Basingstoke: Macmillan Education, 1988): 271-313.

${ }^{39}$ Following Laclau and Mouffe, the concept of 'empty signifier' supposes the political phenomena of a relatively stable discourse order, which coincides with the hegemonic logic of 'determination'. The process of determination fixes the semiotic meaning of 'floating signifiers' according to mainstream 'nodal points'.

${ }^{40}$ See for example Veera Laine, "State-Led Nationalism in Today's Russia: Uniting the People with Conservative Values?", The Finnish Institute of International Affairs Working Paper, October 2016.

${ }^{41}$ Raymond Williams, Marxism and Literature (Oxford: O.U.P, 1977). 
shift in the one-party government rearticulated the core elements of political discourse and then mediated them as a regime of truth. In doing so, I am analyzing a complex of discourses (proposals, drafts, amendments, reports of Duma discussions, public internet debates and expertise reviews) associated with the initiation, creation, revision and adoption of the 'Principles of State Cultural Policy of the Russian Federation' (PSCPRF 2014).

In order to grasp the pivotal moment of the official ideology, we have to look at the legislation on culture from a historical perspective. Back in 2008-2009, the Ministry of Culture of the Russian Federation initiated the engineering of a brand-new federal law on culture. It was justified by the backwardness of Russian legislation in the sphere of culture, which could not cope with the upcoming challenges of modernity. Several governmental bodies commissioned research structures, and high-profile institutes were involved. The NGO foundation Institute of Economic and Social Policy (INESP) (http://www.inesp.ru), the Committee on Culture of the State Duma of the Russian Federation, the Russian Institute of Culturology and some representatives from the Presidential Committee on Culture were among them. According to its working report ${ }^{42}$, the Institute of Economic and Social Policy foundation was in charge of elaborating a draft of the federal law, while the other participants carried out functions of a closed expertise community, e.g. contestation, correction and justification. The original aim was to draw up a law of a higher jurisdiction, which would meet social and economic trends in cultural development, corresponding to the main

${ }^{42}$ Sergey Sidorenko, "Otchet o Rezul'tatakh Okazaniya Uslug po teme: Razrabotka proekta Federal'nogo zakona 'O kul'ture v Rossiiskoi Federatsii" ["Report on the results of the provision of services on the theme: Development of the draft federal law 'On culture in the Russian Federation"'], Gosudarstvennyi kontrakt, no. 3137-01-41/01-JuSh ot 21.08.2009 [State contract number 3137-0141/01-S, 21 August 2009], http://www.inesp.ru/special_projects/culture/info/ (accessed 10 February 2017). 
documents of UNESCO, and take 'international best practices' as a starting point, e.g. in relation to 'the constitutional rights and freedoms of man. ${ }^{\text {,3 }}$

According to the initial concept of the future law, ${ }^{44}$ which was designed by the Institute of Economic and Social Policy, the Russian Federation of those days tended to embrace the notion of 'knowledge economy' by stressing the role of 'human capital' and its fostering. Particularly, this document emphasized:

(1) 'The growing demands in cultural and creative self-expression', which go hand in hand with 'the development of personality';

(2) 'The necessity of qualitatively new levels of development of cultural and educational activity' (e.g. libraries, exhibitions, archives, cinema, conservation and popularization of tangible and intangible culture);

(3) 'The creation of conditions for cultural adaptation to the market environment on the basis and by means of information technologies and wide usage of mass media communications ${ }^{45}$ (translated by the author from Russian).

The ultimate purpose of this law was the 'improvement of the quality of life of the Russian population', and the 'subject of the regulation' defined a set of 'social relations in the sphere of culture and its legal, institutional, economic and social framework for activity ${ }^{46}$. These core characteristics of the document remained valid during 2009-2011 when it was submitted for expert assessment at a parliamentary hearing on 19 April 2010 and at a Duma discussion in October 2011. A discursive analysis of the pre-2012 sources discloses the strong intention of the Russian government for cooperation with the European Union and its

\footnotetext{
${ }^{43}$ Ibid., 1.

${ }^{44}$ Ibid., 2-3.

${ }^{45}$ Ibid., 1.

${ }^{46}$ Ibid., 5 .
} 
willingness to operate with a broad definition of culture ${ }^{47}$. Culture was seen as 'a set of inherent distinctive social attributes, values, traditions and beliefs, finding expression in life and $\operatorname{art}^{48}$.

On the one hand, such vague definitions expanded the semantic borders of what might be considered culture, which brought it closer to the pro-European or liberal agnostic and non-specific understanding of culture 'in whatever sense ${ }^{\text {, }}$. In other words, culture was not prescribed. On the other hand, culture was defined by a logic of differentiation. Thus, there was no contrast or opposition in what can be defined culture or cultural activity. Rather, the construction of cultural identity occurred through the acknowledgment of 'cultural diversity', 'heterogeneity of cultural values and norms' and 'cultural creativity', which was described as an ongoing process of 'modernization and innovation', as well as an activity in the 'creation of cultural values and their interpretations ${ }^{50}$ (translated by the author from Russian).

It is worth mentioning that the visible legislative activity halted at the end of 2011 and resumed in 2014. The examination of numerous editions of this draft and the outcome of its

${ }^{47}$ See the draft law "On Culture in the Russian Federation" of 2011, e.g. "Proekt Federal'nogo zakona 'O kul'ture v Rossiiskoi Federatsii'” (redaktsiya Komiteta Gosudarstvennoi Dumy po kul'ture), 26 October 2011, http://www.inesp.ru/special_projects/culture/info/ (accessed 10 April 2017).

${ }^{48}$ Ibid., 1.

${ }^{49}$ For this argument, see Jeremy Valentine, "Cultural Governance and Cultural Policy: Hegemonic Myth and Political Logics", in Victoria Durrer, Toby Miller and Dave O'Brien eds., The Routledge Handbook of Global Cultural Policy (London: Routledge, forthcoming).

50 “Proekt Federal'nogo zakona 'O kul'ture v Rossiiskoi Federatsii'” (redaktsiya Komiteta Gosudarstvennoi Dumy po kul'ture), 26 October 2011: 2, http://www.inesp.ru/special_projects/culture/info/ (accessed 10 April 2017). 
discussion in governmental bodies shows that the document retained its original character until the end of 2011. Another important point to note is that this particular draft law was not subjected to public discussion during the pre-2012 period. The discursive formation was limited to a group of selected experts and government officials. The same document with a completely different ideological background and under the name 'Principles of State Cultural Policy of the Russian Federation' (PSCPRF) was announced for public discussion on the official website (http://obsudiproekt.ru/) on 23 May 2014. The process of preparing the new version remains unclear due to the lack of government transparency in this particular period of time ${ }^{51}$. There is only one official reference to this matter. An order of the administration of

${ }^{51}$ Before 2011, there was only one official resource with open access information on this legislative initiative. It was on the website of the responsible foundation (http://www.inesp.ru/special_projects/culture/info/). After 2014, more than 5 official resources were launched by governmental bodies and party-commissioned foundations in order to cover the process of adoption of the law and its legal basis (for instance, see "Obsuzhdaem Proekt: Osnovy gosudarstvennoi kul'turnoi politiki" ["Discuss: the basics of state cultural policy"], Vsemirnyi Den' Kul'tury [World Culture Day], http://udculture.info/newsru/osnovyi-gosudarstvennoy-kulturnoypolitiki/; "Utverzhdeny Osnovy gosudarstvennoi kul'turnoi politiki” [“Approved principles of state cultural policy"], Prezident Rossii [The President of Russia], http://kremlin.ru/events/president/news/47325; "Ministerstvo kul'tury priglashaet k obshhestvennomu obsuzhdeniyu proekta Osnov gosudarstvennoi kul'turnoi politiki” [“The Ministry of Culture's invitation to public discussion of the draft principles of state cultural policy"], Ministerstvo kul'tury Rossijskoj Federatsii [Ministry of Culture of the Russian Federation], https://www.mkrf.ru/press/news/ministerstvo-kultury-priglashaet-k-obshchestvennomuobsuzhdeniyuproekta-osnov-g/?sphrase_id=80735; "Proekt "Osnov gosudarstvennoi kul'turnoi politiki" ["The project 'Principles of State Cultural Policy'"], Rossiiskaya Gazeta [Russian Newspaper], https://rg.ru/2014/05/15/osnovi-dok.html, etc.). 
the President of the Russian Federation (23 January 2014, N. 79) affirms that the 2014 version of the draft was elaborated by a working group led by Sergei Ivanov, Head of the Presidential Administration.

Therefore, the new document not only changed its name from 'Draft Federal Law on Culture' to 'Principles of State Cultural Policy of the Russian Federation', but it had also undergone several other changes. It is worth remembering that it was initially conceived as a federal law on culture, which has higher judicial power after the Constitution of the Russian Federation. However, since the draft of the PSCPRF was highly criticized by professionals and the academic community during the so-called public discussions in May 2014, its final draft failed to gain public support and was revised with 'public suggestions' and hastily approved by a decree of the President on 24 December 2014. In this way, the PSCPRF obtained the status of a decree. In terms of the current legislative system of the Russian Federation, decrees of the President have less judicial power than the Constitution or federal laws.

However, the adopted document became part of the 'strategy of national security' and gained supreme political power. At the beginning of the text, there is a statement that the PSCPRF as part of the strategy of national security is the basic document to define any 'legislative and other normative legal acts in the Russian Federation, which regulate the processes of cultural development' in the country ${ }^{52}$. In this way, the decree tends to exercise power over further federal laws on culture and any other normative acts in this sphere. Moreover, in accordance with this symbolic document, the one-party government urgently started a mechanism of knowledge production. For instance:

\footnotetext{
${ }^{52}$ Ministry of Culture of the RF, "Osnovy Gosudarstvennoi Kul'turnoi Politiki" ["Principles of State Cultural Policy of the Russian Federation"] (Ministry of Culture, 2015): 3.
} 
- The newly 'optimized' Russian Research Institute for Cultural and Natural Heritage of D.S. Likhachev ${ }^{53}$ contributed to the official issue of the PSCPRF by producing the chapter 'Basics of "the Basics": About the meaning of state cultural policy" ${ }^{54}$. The chapter starts with the following statement about the PSCPRF: '[a]s a political document, it is based on certain philosophical assumptions. However, the type of the legal text does not assume a detailed description of these prerequisites; they are only indicated or implied ${ }^{55}$ (translated by the author from Russian). The chapter includes so-called academic clarifications that aim to explain and verify the controversial points of the document by means of scientific sophistry and even with reference to the UNESCO Declaration of Cultural Diversity. For example, the beginning of the chapter introduces a concept of culture borrowed from the UNESCO declaration in a cropped form: culture is described 'as the set of distinctive spiritual, material, intellectual and emotional features of society or a social group' ${ }^{56}$ only, without any reference to 'the diversity of cultures, tolerance, dialogue and cooperation' ${ }^{57}$. On the basis of this, it is possible to talk 'about culture as the essence and basis of our [Russian] identity'. Further, the text redefines the meaning of culture within cultural traditionalism, unification and essentialism. In this respect, culture is rearticulated as 'a social mechanism for the transfer of collective knowledge and system of values' and a normative regulatory system of social

${ }^{53}$ Before 2014, there were two separate universities, Likhachev's University and the Institute of Russian Culture. They were merged in 2014 by an order of the Ministry of Culture of the RF.

${ }^{54}$ Ministry of Culture of the RF, "Osnovy Gosudarstvennoii Kul'turnoi Politiki" ["Principles of State Cultural Policy of the Russian Federation"] (Ministry of Culture, 2015): 23-42.

${ }^{55}$ Ibid., 23.

${ }^{56}$ Ibid., 25.

${ }^{57}$ UNESCO Universal Declaration on Cultural Diversity. UNESCO, 2001. 
reproduction with 'a fixed set of values, which are immanent to a specific social organism'58. Thereafter, cultural separatism and cultural conservation are justified by the argument that 'the absence of this fixed system of values will lead to the formation of an ideological vacuum. It will be filled at random, and as a result, social groups and individuals will adopt such life principles that are incompatible with the existence of society. The lack of a unifying spiritual foundation will lead to a split in society and its collapse ${ }^{59}$ (translated by the author from Russian, emphasis added). In addition to this, the official issue of the PSCPRF was augmented by Putin's quotations and Medinsky's debatable article 'The one who does not feed their culture, will feed a foreign army'. Thus, the political indoctrination aimed at creating antagonism between 'Russian traditional culture' and Western 'degradation and moral crisis ${ }^{60}$ was supported by intellectual and moral forces.

- The Ministry of Culture of the RF opened a call for a 'competition on the elaboration of the best concept of a textbook on the "Principles of State Cultural Policy of the Russian Federation" in $2016^{61}$. In this way, the unification of the educational system will be reorganized through a presidential decree.

Thus, hegemony was established through biopolitical legislation. This process is shown in the

\footnotetext{
${ }^{58}$ Ministry of Culture of the RF, "Osnovy", 24-26.

${ }^{59}$ Ibid., 26.

${ }^{60}$ Ibid., 49-55; 56-69.

61 “Minkul'tury ob'yavilo konkurs na sozdanie luchshei konseptsii uchebnogo posobiia po 'Osnovam gosudarstvennoi kul'turnoi politiki RF"' ["The Ministry of Culture announced a competition to create the best concept of a textbook on the course 'Principles of State Cultural Policy in the Russian Federation"'], Ministry of Culture of the Russian Federation, 25 October 2016, https://www.mkrf.ru/press/news/minkultury-obyavilo-konkurs-na-sozdanie-luchshey-

k/?sphrase_id=92699 (accessed 10 February 2017).
} 
ideological priorities of the entire discourse. The ideological priorities of the narrative shifted from a chain of equivalence that established semantic links between Russian modernization and experience of the Western developed world $($ cosmopolitanism $=$ modernization $=$ integration with Europe) to one that focused on retaining leadership inside the country through the construction of an external enemy (state nationalism $=$ conservatism $=$ cultural separation)

The floating signifier 'culture', which in fact is capable to 'float' and change its meaning within different contexts of exteriority and mainstream nodal points, was fixed as something specific through a dichotomy of high- and lowbrow culture and antagonism between 'European $=$ individualistic $=$ liberal $=$ destructive culture' and 'Russian $=$ collective $=$ traditional $=$ civilizing culture'. For example, the first draft of the PSCPRF (2014) featured such specific and restrictive statements as: 'Russia is a state which has established a great culture', and 'Russia is not Europe ${ }^{, 62}$. In order to grasp the governmental reasoning behind the change in the ideological specificity of the two versions of this one legislative initiative we have to look at it closely in the context of exteriority and marginalization, which took place just between 2011 and 2014.

\section{The Conservative Roots of Russian State Cultural Policy}

In the President's address to the Federal Assembly in 2012, the recently elected Vladimir Putin stressed the main priorities for the development of the country by referring to culture, traditional institutions, nationality, sovereignty of the state and patriotism. According to his speech, 1) patriotism is defined as 'serving society and the country'; 2) 'military power' is the

\footnotetext{
62 "Proekt. Osnovy gosudarstvennoi kul'turnoi politiki" ["The draft document 'Principles of State Cultural Policy'"], Russian Magazine, 16 May 2014, https://rg.ru/2014/05/15/osnovi-dok.html (accessed 10 April 2017).
} 
main 'guarantee of Russian security and independence'; 3) 'traditional values' as well as 'traditional institutions' should be maintained and regenerated in order to improve the situation of 'a clear deficit of spiritual bonds'; 4) 'Russian nationality' has obtained the status of a titular nation that glues the multinational country together as a 'state civilization' via 'Russian people, Russian language and Russian culture' ${ }^{63}$. In this way, addressing the heads of the governmental bodies, he continued that 'any attempts to provoke ethnic tensions and religious intolerance should be considered a challenge to the unity of the Russian state and a threat to all of us ${ }^{64}$ (translated by the author from Russian). Thus, the Russian population was determinedas the 'single Russian nation', and the omission of cultural diversity and heterogeneity from the official rhetoric occurs naturally.

Further on in the address, Putin defined democracy as Russia's specific choice. However, the newly appointed president determined a distinctive understanding of democracy, which was based on his previous reference to Russian traditions, national culture and the sovereignty of the country. It can be described through the following chain of equivalence: 'Russian democracy $=$ the power of the Russian people with its own traditions of self-government $=$ compliance to and respect for established laws, rules and regulations $=$ the foundations of the state and society $=$ the continuity of national development $=$ the indisputability of the sovereignty, rights and freedoms of citizens ${ }^{\prime 65}$. Hence, Putin establishes an equivalence between the people, a political form and the state project.

Since that moment, following the given direction, Russian official discourse has

${ }^{63}$ Vladimir Putin, "Poslanie Prezidenta Federal'nomu Sobraniyu" ["The President's address to the federal Assembly"], Kremlin, 12 December 2012, http://kremlin.ru/events/president/news/17118/work (accessed 10 February 2017).

${ }^{64}$ Ibid.

${ }^{65}$ Ibid. 
continuously established itself against such aspects of Westernization as liberalization and cosmopolitism, which it regards as threats to state sovereignty, Russian unity and social stability. The mottos of the conservative project - 'it is a threat to Russian norms', 'it is a threat to the Russian nation', 'it is a threat to the Russian spirit', etc. - constantly describe national identity and traditional Russian norms as exposed to danger. The frame of the conservative project has been maintained through chains of equivalence and antagonism in official documents (federal laws and amendments) and political discourses, which have been mediated through state television channels. At the same time, in the media these chains of equivalence and antagonism have been contrasted with another empty signifier - 'the West'. Thus, the unitary features of the Russian nation have been constructed on the basis of social antagonism between 'Us' and 'Them' - between Russian civilization and European subversive culture.

In particular, the floating signifier of 'national security' has been articulated in different forms of antagonism (sex- and gender-related, national, cultural, religious, moral and ethical forms), and chains of equivalence ('national security $=$ state intervention $=$ state censorship' and 'true culture $=$ national culture $=$ traditional culture $=$ Orthodox values') in ministerial and political documents. This way, an understanding of what should be considered 'true culture' has been constantly reproduced by the Russian conservative political project, which consists of a complex of power operators. These are the Russian Orthodox Church, state- or party-commissioned foundations (e.g. Russian World and 'Unity in the name of Russia'), the United Russia party, the extensive presidential apparatus and controlled media (by GazpromMedia Holding).

Representatives of the conservative project seek to equate 'cultural people' (on the basis of traditional values and Orthodox morality) with the 'Russian nation' and the 'unity of the nation' with the 'sovereignty of the Russian state' and its military force. For example, an extract from Putin's Valdai speech in 2013 was quoted, reproduced and 
repeated many times in the media, in the speeches of loyal politicians and strategic documents. In it, Putin claimed:

What else can be the greatest testimony of the moral crisis of human society, if not the loss of the ability of self-reproduction? Today almost all developed countries already cannot reproduce, even with the help of migration. Without the values embedded in Christianity and other world religions, without thousands of years of evolving norms of morality and character property, people will inevitably lose their human dignity. And we [Russian people] consider it to be natural and correct to defend these values ${ }^{66}$.

After 2012, a significant increase in regulative and restrictive activity, as well as state intervention into culture and education ${ }^{67}$ have reduced the civil rights and political options of Russian citizens. The following discourse analysis suggests that the conservative hegemony has been maintained through discourses which have political or symbolic power rather than a judicial status. It can be claimed that the biopolitical mechanism of the conservative project outflanked the procedures of the legislative system when there was a need to change the ideological background of the governmental apparatus.

In this context, looking at the latest period of official discourses on culture, several conceptual transformations can be defined in normative documents. First, all the post-2014 official documents stress the fusion of 'the state' and 'the population' as one single abstraction. As a result, the political construction of 'the Russian people' as a single 'national identity' and the acknowledgement of cultural values only in a limited set of cultural patterns provide a ground for the legitimation of sociocultural marginalization and censorship. The naturalization of the 'unitary subject' occurs through the following chain of equivalence: 'the

\footnotetext{
${ }^{66}$ Ministry of Culture, “Osnovy Gosudarstvennoi Kul’turnoi Politiki”, 52.

${ }^{67}$ Oksana Moroz, "Strategii rossiiskoi gosudarstvennoi kul'turnoi politiki: opyt rassledovaniya"
} ["Strategy of Russian state cultural policy: the experience of the investigation"], Neprikosnovennyj Zapas 107, no. 3 (2016), http://www.nlobooks.ru/node/7434 (accessed 10 April 2017). 
Russian country $=$ the Russian state $=$ the Russian people'. For instance, the diversity of 'the people' (e.g. groups, classes, communities, identities, etc.), their concrete needs, motives and concerns are never mentioned in the new flow of concepts and the related expertise (e.g. recommendations, reports and propositions from expert groups). Thus, the horizon of differentiation of public-private-state relations is reduced. Consequently, cultural heterogeneity is neglected. In ministerial and Kremlin discourses, the concept of culture is rearticulated using the following chain: 'cultural heritage $=$ national culture $=$ highbrow culture $=$ traditional culture'. Moreover, these all are seen to be 'a subject' of the state's regulation and conservation from what is considered the destructive influence of Western and mass culture. In the final version of the PSCPRF, even 'cultural diversity' has been omitted, and the concept has completely disappeared from the 2014 edition.

Secondly, 'cultural and humanitarian development' is mainly seen to serve the 'economic growth, state sovereignty and civilizational distinctiveness of the country' ${ }^{68}$, and to be in an antagonistic relationship to popular and mass culture, which exist in line with 'the will of "the unseen hand of the market" (i.e. cultural degradation) ${ }^{96}$. In this context, 'culture' is understood in terms of LIKBEZ (a Soviet programme of liquidation of illiteracy). Initially, this socialist programme struggled for the right of all people for basic education according to the priorities of the one-party dictatorship ${ }^{70}$. But in fact, culture and its civilizational potential were applied as a tool to cultivate and replicate standardized members of the only permissible

\footnotetext{
${ }^{68}$ Ministry of Culture of the RF, "Osnovy Gosudarstvennoi Kul'turnoi Politiki" ["Principles of State Cultural Policy of the Russian Federation”] (Ministry of Culture, 2015): 3.

${ }^{69}$ Ibid., 35.

${ }^{70}$ Vladimir Lenin, "Speech at the First All-Russia Congress of Workers in Education and Socialist Culture", Pravda, 31 July 1919, https://www.marxists.org/archive/lenin/works/1919/aug/05.htm
} (accessed 20 October 2017). 
social group. Little Octobrists, Pioneers, Komsomol and Communists presented a set of socially and politically recognized identities. To put it simply, only a true member of the Communist party, with one aim to move through socialism towards Communism and with one faith in Communism, could obtain the status of normality in Soviet society. Through politically marking each biological phase of human development in line with the ideology of the single party, all individuals were subjected to the indoctrinated governmental reason even before they were born. And today, once again, the Russian government is committed to fulfilling its obligations in respect of the 'cultivation of the contemporary individual and whole society in accordance with traditional moral values ${ }^{\text {,71. }}$.

Likewise, the PSCPRF does not stress the contribution of 'cultural development' to individual prosperity, a variety of sociocultural and political demands, the fulfilment of human rights and liberties or the development of a sustainable environment for everyone's creative potential, as it did in the 2011 draft. Instead, it mentions that one of the 'tasks of state cultural policy' is the 'identification of gifted and talented children in different areas and the creation of conditions for their individual learning,72. 'The rise of individualism' is determined as one of the "most dangerous phenomena of the Russian future' ${ }^{73}$. Furthermore, the normative act refers to the Russian Constitution regarding the fact that the " $[\mathrm{r}]$ ealization of individual rights and freedoms is limited to the extent that the "performance of the rights and freedoms of man and citizen shall not violate the rights and freedoms of other persons" Consequently, federal legislators are able to restrict the rights and freedoms of men and citizens "to protect the foundations of the constitutional system, morality, health, rights and

\footnotetext{
${ }^{71}$ Ministry of Culture, “Osnovy”, 36.

${ }^{72}$ Ibid., 11, 17

${ }^{73}$ Ibid., 6

${ }^{74}$ Ibid., 45 .
} 
lawful interests of other persons, national defence and state security""75 (translated by the author from Russian). Thus, we can conclude that the political conservative project mobilizes the cultural terrain as the largest part of the political regime. In doing so, culture is fixed as conservative through discourses of values, patriotism and orthodox morality. It is worth mentioning at least two main implications that follow from this.

First, the conflict between the democratic constitutionalism of the Russian Federation and the sovereignty of the Russian state is negated in the political rhetoric and denied in social norms and legislative practices. In this way, the significance of protecting constitutional human rights and freedoms disappears in the ideological struggle, and the 'empty place of power" ${ }^{76}$ is filled with the growing tension over state sovereignty. Partly, it can be characterized as a legal suspension of the constitutional rights of an individual or a group as well as their banishment from the political terrain of ideological struggle in the name of national security or maintaining stability. Second, the new borders of inclusion and exclusion are created inside 'the people'. The political construction of 'the Russian people' is divided into those who belong to the Russian nation with 'true cultural' patterns and those who belong to the marginalized cultural minorities. Consequently, the hegemonic practices of the titular group expel and restrain the cultural heterogeneity and ambiguity of artistic and also civic creativity. Looking at this problem from a different viewpoint ${ }^{77}$, one sees that the Russian conservative project has a tendency to occur through 'moral oversight' over the whole nation and party-state interventions into the private lives of individuals.

The cultural indoctrination of the conservative regime prevents the emergence of a

\footnotetext{
${ }^{75}$ Ibid., 45.

${ }^{76}$ Laclau and Mouffe, Hegemony, 98.

${ }^{77}$ Andrey Makarychev and Sergei Medvedev, "Biopolitics and Power in Putin's Russia", Problems of Post-Communism 62, no. 1 (2015): 45-54.
} 
collective struggle between a large 'us' and a small 'them' inside the country, i.e. between a wide variety of cultural diversity of 'the people' and the ideological state apparatus. Consequently, multiple forms of activism lose their role in the political struggle, being disavowed by the political supremacy of nationalistic Orthodox morality. Such a scarce regime of political debate eliminates the ambiguity of the articulative practice of art, culture and individuality and neglects the differentiation of the floating signifiers 'human rights', 'human freedoms' and 'human body'. The next section is an attempt to support this conclusion with evidence from two recent case studies.

\section{'No' to Controversial Art, 'Yes' to Deductive Art}

Despite the biopolitical hegemony of conservative and traditional culture, a different discursive community appeared in the public space, aimed at subverting the Kremlinsupported cultural regulation after the incident with Jock Sturges' exhibition in Moscow. Advocating the ambivalence of art and culture, several representatives of the creative class lambasted the censorship imposed by Kremlin officials and state-commissioned NGOs. Konstantin Raikin, the head of the Moscow Satyricon Theatre, made a strong statement against censorship in art at the VII Congress of the Union of Theatre Professionals of Russia and later at the Public Chamber of the Russian Federation. He claimed that the 'current struggle for morality is false'. Ridiculing the conservative position, Raikin challenged the inaction of the government: 'Don't you want to put underwear on David and a bra on Venus? The main thing in art is the way to see it $^{78}$ (translated by the author from Russian). Discussions in social media subverted the official point of view by using satire and humour.

\footnotetext{
78 "Naden'te trusy na Davida: kak v Obshchestvennoi palate obsuzhdali vvedenie tsenzury"["Put a pair of pants on David: how the censorship was discussed at the Public Chamber of the Russian Federation"], AfishaDaily, 18 October 2016, https://daily.afisha.ru/brain/3312-nadente-trusy-nadavida-kak-vobshchestvennoy-palate-obsuzhdali-vvedenie-cenzury/ (accessed 20 October 2016).
} 
Internet users ridiculed official political claims with exaggeration and overdetermination of moral statements, in particular those made by Mizulina. Using hashtags 'MisulinaArt' or 'HelpMizulina', people invited each other to join the so-called 'paedophile movement' and post their nude baby photos from Soviet times. Russian folklorists suggested calling this phenomenon 'playing solidarity"79.

An example of a cultural attempt to subvert the dominant political articulation of the opposition between the 'body' and 'national decency' in keeping with the Orthodox principles of the conservative mores is presented by the exhibition titled Knight of Despair/Warrior of Beauty by the Belgian multidisciplinary artist Jan Fabre. The exhibition opened at the State Hermitage Museum in St. Petersburg on the $22^{\text {nd }}$ of October 2016 and featured stuffed animals in strange poses. An analysis of the discursive formation around the event shows that the negative attitude to this exhibition was initially proposed by comments from several media sources. For example, a magazine affiliated with one pro-conservative foundation ${ }^{80}$ questioned the appearance of 'strange exhibits among the masterpieces of the country's main museum ${ }^{81}$. On the NTV-St. Petersburg channel, the event was named an 'outrageous exhibition' a day before its opening. 'The first thing that can be said about Jan Fabre is that he is an artist who has his closet full of skeletons, and now they are all in the Hermitage', was one value judgment that characterized 'Jan Fabre's phenomenon' in a

\footnotetext{
${ }^{79}$ Arkhipova, "Pochemu Mizulina - eto seksi, a nagota - eto strashno?"

${ }^{80}$ For more information, see the website of the NGO The Foundation of Historical Perspective (http://www.fiip.ru/about/).

${ }^{81}$ Andrey Sokolov, “Strannye eksponaty poiavilis' sredi klassicheskikh shedevrov glavnogo muzeia strany" ["Odd exhibits appeared among the masterpieces of the country's main Museum"], Stoletie [Century], 20 October 2016, www.stoletie.ru/kultura/monstry_v_ermitazhe_644.htm (accessed 20
} October 2016). 
nutshell ${ }^{82}$.

The public reaction to this event evolved into antagonistic pro and contra debates. The crucial question was whether the Hermitage is a suitable place for a controversial art project. Several news channels reported that 'shocked visitors, animal rights activists and the Russian Orthodox Church dubbed the event as disgusting and inappropriate ${ }^{83}$. Vitaly Milonov, one of the most fundamentalist Russian politicians, accused the Hermitage administration of 'complete idiotism' and 'once again smearing Russian art and the great temple with vulgarity and filth ${ }^{84}$. He spoke out against 'particular people', who were disposing of the museum 'the way they want'. Finally, Milonov concluded that the museum is not 'a garage or private sauna. It is a state museum. It means that the exhibitions should serve the interests of the state 85 . In an interview, several representatives of the Orthodox Church compared the stuffed

82 "Epatazhnaia vystavka Yana Fabra otkrylas' v Ermitazhe" ["Shocking exhibition of Jan Fabre opened in the Hermitage"], NTV-St. Petersburg, 21 October 2016, http://www.ntv.ru/video/1325951/ (accessed 30 October 2016).

${ }^{83}$ Alexey Danichev, "Pochemu vystavka Jana Fabra v Sankt-Peterburge obernulas' skandalom?" ["Why is the exhibition of Jan Fabre in Saint-Petersburg turned into a scandal?"], RIA News, 16 November 2016, http://inosmi.ru/social/20161116/238221628.html?utm_source=tw1 (accessed 30 November 2016).

${ }^{84}$ Sasha Sulim, "Heshteg \#pozorErmitazhu. Glavnoe za chto Elena Vaenga, Vitalii Milonov i zashchitniki zhivotnykh opolchilis' na vystavku Jana Fabra" [“The hashtag \#Shame of you Hermitage. The main thing that Elena, Vitaly Milonov and animal advocates took up arms on the exhibition of Jan Fabre"], Meduza, 13 November 2016, https://meduza.io/feature/2016/11/13/heshtegpozorermitazhuglavnoe (accessed 30 November 2016).

${ }^{85}$ Ibid. 
animals to the art of witchcraft and 'occultism'86. The 'against' movement was created on Instagram and Twitter by angry and frustrated visitors. According to a RIA News report on 16 November 2016, 'thousands of Russian internet users protested against the presence of the stuffed animals at the Hermitage, ${ }^{87}$. However, after a closer analysis, one sees that there were less than a thousand comments on the subject, many of which were reposted from one social network to another. The public outrage on Instagram escalated and subsided within one week, from the $11^{\text {th }}$ to the $18^{\text {th }}$ of November. By the hashtag 'Shame on you, Hermitage', users expressed hard feelings: 'I cannot remain indifferent. I'm not against art but I am promorality, shame on you, Hermitage. ${ }^{88}$

However, the controversy also shows the emergence of an antagonistic space, at least within social media, through which hegemony is maintained. I carried out an exploration of the discourse formation on the internet around the exhibition. I analyzed three social networks, three petitions and related comments, and comments on media reports and magazine articles on the subject (in total more than 800 comments) during the period from 20 October to 28 November. According to the results of a critical discourse analysis, a few participants made all the comments on the related media reports and petitions. In general, the 'against' community articulated two main subjects in the discussion. The first described their personal perception of the exhibition. Basically, it was expressed in an offensive language in relation to Jan Fabre, his art and the Hermitage's top managers. Many people enjoyed

\footnotetext{
86 "V rabotakh Jana Fabra net mesta ni Bogu, ni cheloveku" ["In the works of Jan Fabre there is neither God nor man"], Interfax, 18 November 2016, http://www.interfaxreligion.ru/?act=interview\&div=467 (accessed 30 November 2016).

${ }^{87}$ Danichev, “Pochemu vystavka Jana Fabra v Sankt-Peterburge obernulas’ skandalom”.

88 The State Hermitage Museum, the official website, 11 November 2016, www.hermitagemuseum.org/wps/portal/hermitage (accessed 30 November 2016).
} 
exercising legitimate verbal violence towards the controversial artist and those who allowed this insult against the Hermitage foundation and the whole Russian nation. Quite often, these champions of morality used abusive language: 'Shame!!!! Such exhibitions are banned in Europe, so they make their rotten exhibition here in our country, hang by the balls this Fabre!' or 'No sense, no imagination there, but what happened to morality? Why do you disgrace our country? ${ }^{89}$ (translated by the author from Russian). However, after the escalation of the public scandal, many 'frustrated and offended' commentators deleted their posts and comments, which might be considered to indicate a shift in their mindset. Typically, the judgemental statements shared common adjectives and expressions, such as 'shame', 'horror', 'slaughter', 'mentally sick', 'propagation of violence', 'corpses', 'abomination', 'death', 'degradation' and 'beast'. Their frequency of use varied from the most often used 'shame!' (about 300 mentions), addressing the Hermitage, to the less repeated 'beast' (about 25 mentions), which described the artist.

The second articulated subject was related to censorship. Petitions were sent to President Vladimir Putin, Minister of Culture Vladimir Medinsky and Governor of St. Petersburg Georgy Poltavchenko. Frustrated people asked authorities at different levels to 'close the cruel exhibition of Fabre-the-butcher at the Hermitage' ${ }^{\prime 9}$. With reference to the federal law 'On the Protection of Children from Information Harmful to their Health and

${ }^{89}$ The exact comments from the Hermitage Instagram: "Pozor!!!! \#pozorermitazhu v Evrope zapreshcheno, tak oni u nas ustraivaiut svoi gnilye vystavki, za iaitsa podvesit' etogo Fabra!", and "Ni uma, ni fantazii net, no moral' to kuda delas'? Zachem vy nashu stranu pozorite?" (translated by the author from Russian). For more, see Instagram of the State Hermitage Museum, www.hermitagemuseum.org/wps/portal/hermitage (accessed 30 November 2016).

${ }^{90}$ Petr Charushin, "Zakryt' zhestokuiu vystavku zhivodera Fabra v Ermitazhe”, Change. Org Russia, 11 November 2016, https://www.change.org (accessed 30 November 2016). 
Development', people demanded that the exhibition should be shut down and Mikhail Piotrovskiy, the Director of the State Hermitage Museum, penalized. Many comments from the community appealed to the repressive institutions and their oversight and prohibitive functions, asking for an authority or an abstract supervisory power to stop the chaos. Thus, instead of taking responsibility for their children, people chose the strategy of total submission to a law which is advisory in nature.

The discursive 'pro' community was initiated by Dmitry Ozekov, the manager of the exhibition at the Hermitage. Under the hashtag 'Cats pro Fabre', the liberal community of artists published a series of articles that discussed the ambiguity of art and its means of expression $^{91}$. In a reply to the allegations of cruelty towards animals, the employees of the Hermitage reminded onlookers that in the 1990s, the museum was a shelter for abandoned stray cats. Mikhail Piotrovsky, the general director of the Hermitage Museum, assumed that these public attacks on the exhibition 'have shown the overall level of hatred that exists in Russia, hatred for the other ${ }^{92}$. Finally, the exhibition continued to operate as normal until the end of April 2017 due to the high reputation of the museum in political circles and the substantial support from the artistic community.

However, it is also obvious that in this case the issue of social antagonism did not lead to the contestation of the ruling class-generated ideological set of meanings and values. The

\footnotetext{
91 For more, see "\#koshkizaFabra", Twitter, 17 November 2016, https://twitter.com/hashtag/\%D0\%BA\%D0\%BE\%D1\%88\%D0\%BA\%D0\%B8\%D0\%B7\%D0\%B0\% D0\%A4\%D0\%B0\%D0\%B1\%D1\%80\%D0\%B0?src=hash (accessed 30 November 2016).

${ }^{92}$ Mikhail Piotrovsky, "Sovremennoe iskusstvo: poklonniki i protivniki”, Radio Echo of Moscow, 22 November 2016, http://echo.msk.ru/programs/beseda/1878682-echo/ (accessed 30 November 2016).
} 
subversive potential of cultural ambiguity was not converted into 'counter conduct' ${ }^{93}$, which as an analytical category grasps the political radicalization of the hegemonic order. For instance, supporters of contemporary art, in general, did not try to find constructive dialogue with the 'against' representatives. Instead, both sides named each other 'sick', 'mad' and 'daft'.

In the same way, the dialogue between the Hermitage and the general public failed. For instance, in the introduction of the exhibition leaflet, Mikhail Piotrovsky expresses the common artistic view on cultural intolerance but does not challenge its ideological justification (e.g. forms of control and social relations of subordination and domination). $\mathrm{He}$ states that 'the Hermitage is fond of using the whole context of its encyclopedic collections and interiors for a cleverly structured dialogue between cultures' and is 'a playground' for cultural events despite the observed 'reactions of the public, particularly at this exhibition, when visitors sometimes failed to notice or did not want to notice semantic and aesthetic nuances and subtexts ${ }^{94}$.

As for online media, the current Facebook, Twitter or Instagram discussions involve specific features of polarization. This confrontation is evident in the 'yes/no' comments and the lack of dialogue, reasoning and negotiation, which raises questions of whether this specific form of communication in social networks derives from the technological transformations or is a manifestation of social despair.

\section{A Final Thought}

\footnotetext{
${ }^{93}$ Michel Foucault, “The Political Technology of Individuals" in L. Martin, H. Gutman and P. Hutton eds. Technologies of the Self a Seminar with Michel Foucault (London: Tavistock Publications, 1988): $145-163$.

${ }^{94}$ Mikhail Piotrovsky and Jan Fabre, Knight of Despair/Warrior of Beauty, exhibition catalogue, The State Hermitage Museum (St. Petersburg: Skira, 2016).
} 
It should not be forgotten that before the 2012 conservative turn in politics, Russian 'common sense' welcomed cultural ambiguity and heterogeneity. For example, Verka Serduchka, a Ukrainian transgender comic character, or Boris Moiseev, a Russian gay singer, and many other controversial pop artists were all the most beloved heroes of Russian popular shows, theatres, festivals and films before 2012. On top of that, the naked body irrespective of age and gender has traditionally been an apolitical figure. Unisex saunas in the Russian countryside as well as in big cities are the best evidence of that.

Moreover, even now different dimensions of transgressive popular culture still exist in Russia. For example, in August 2017 the internet show Versus Battle between two Russian rappers, Oxxxymiron and Rapper Purulent (Glory CPSU), which was released on YouTube, gained more viewers even than Direct Line with Vladimir Putin in June $2017^{95}$. According to the subsequent discussions on social media, many Facebook users had no idea about the existence of such a widespread subculture and its level of consumption. And it is clear why. Imitations of American rap culture, as many other dimensions of Russian-American, RussianEuropean and Russian-cosmopolitan contemporary culture of this kind, do not receive any financial or political support from the Russian state, are not visible on Russian television and are not included in the ministerial concept of what culture is supposed to be.

Notwithstanding, a variety of popular cultures flourish in spaces free from governmental regulation, monitoring and control. For instance, a post-Crimea satire on the Russian-language internet is an illustrative phenomenon of irrepressible counter-conduct which 'may destabilise dominant narratives of the ontological security and challenge their

\footnotetext{
95 Marc Bennetts, "Hip-hop star Oxxxymiron uses rap for Russian culture debate", The Times Moscow, 17 August 2017, https://www.thetimes.co.uk/article/hip-hop-star-oxxxymiron-uses-rap-forrussianculture-debate-86wbprlz9 (accessed 1 November 2017).
} 
strives towards closure' ${ }^{\prime 96}$. Such marginalized, on the one hand, and overlooked, on the other, cultural heterogeneity can be seen as a multitude of moral, economic and intellectual forces, which, if successful, can obtain political leadership. And this is evidence of the weakness of the current hegemony.

${ }^{96}$ Emil Edenborg, "Creativity, geopolitics and ontological security: satire on Russia and the war in Ukraine”, Postcolonial Studies 20, no. 3 (2017): 294. 